\title{
Beach erosion management in Small Island Developing States: Indian Ocean case studies
}

\author{
V. Duvat \\ Department of Geography, Institute of Littoral and Environment, \\ La Rochelle University, France
}

\begin{abstract}
In Small Island Developing States (SIDS), the questions of coastal erosion and sea defence structures raise specific issues that this paper will discuss in light of the analysis of the situations in Seychelles and Mauritius. These questions relate back to the role of post-colonial development strategies and have close ties with tourism as beaches have an important economic value. Thus, beach erosion has become a major concern both for the authorities, which lack well-documented analyses as well as the technical and financial capacities for developing appropriate strategies, and for tourism operators. The lack of consistent policies often leads to the systematic use of hard engineering structures without any consideration either for coastal dynamics or socioeconomic factors. Nevertheless, in western Indian Ocean states, beach erosion management has evolved positively for the past 15 years under the influence of internal and external factors. The respective roles of the Regional Environment Programme of the Indian Ocean Commission and of the initiatives of tourism operators in recent progress will be highlighted.
\end{abstract}

Keywords: beach erosion, coastal protection works, tourism development, Small Island Developing States, Indian Ocean.

\section{Introduction}

Worldwide beach erosion became apparent during the 1980s due to the works of the International Geographical Union working group on the Dynamics of Coastal Erosion (1972-1976) and the successive Commission on the Coastal Environment (1976-1984). Two hundred participants belonging to 127 countries contributed to a survey that showed that 70 per cent of the world's sandy coasts 
experienced net erosion while 10 per cent sustained progradation and 20 per cent were stable [1]. This survey and the associated works have provided a valuable analysis on the situation of tropical beaches and demonstrated that they were severely affected by shoreline retreat as many coastal areas are located in tropical cyclone tracks [2]. In parallel, the development of coastal tourism and the issues related to climate change and coral reef degradation, which were identified as the main causes of beach erosion, encouraged further scientific studies and expert analyses of beach dynamics and evolution [3, 4].

In Small Island Developing States (SIDS), conducting research into beach erosion has often been made difficult by limited national capacities; regional development programmes have therefore provided useful support. In the 1980s, coastal erosion was identified as a main concern for island states of the western Indian Ocean, however, scientific research, expert analyses and training were only undertaken in the middle of the 1990s when the Regional Environment Programme of the Indian Ocean Commission was launched with the support of the European Union (1995-2003). In such context, on the basis of case studies of the Republic of Seychelles and Mauritius (including the autonomous island of Rodrigues), this paper will highlight and discuss beach erosion management practices. It is based upon the findings of the scientific research carried out by the author from 1996 to 2008 (The author completed her PhD thesis on beach geomorphology and management in Seychelles in 1998. She has carried out research on coastal geomorphology and management in western Indian Ocean islands from 1996. She conducted expert analyses and participated in the launching of regional training programmes on beach dynamics and management, in particular in Seychelles and Mauritius, at the Indian Ocean Commission's demand (see references).). After a brief presentation of the coastal physical settings, we will present the importance and causes of beach erosion and underline the role of coastal development practices in sediment cell destabilization. Then, through the analysis of beach erosion control techniques and policies, we will demonstrate what features the Seychelles and Mauritius have in common as SIDS. Finally, factors of progress and recent trends in beach erosion mitigation will be brought to light, and drivers of erosion control will be discussed.

\section{Beach erosion in Seychelles and Mauritius}

\subsection{The situation of Seychelles}

\subsubsection{The state of beaches}

The granitic islands of Seychelles consist of 41 mountainous islands and islets that rise to a maximum height of $915 \mathrm{~m}$ at Morne Seychellois on Mahe. Since colonization times, the steep, rocky and unstable weathered slopes of the four main islands (Mahe, Praslin, Silhouette, la Digue) have encouraged human communities to settle in the narrow and scattered coastal plains which cover $15 \%$ (Mahe) to $30 \%$ (Praslin and la Digue) of the land area. Most of these plains are less than 700 metres wide and no more than one kilometre long. They are 
bordered with fringing coral reefs that have played a major role in the formation of sandy beaches as the terrigeneous material brought to the shore by rivers never exceeds $30 \%$ of the sediment budget of beaches. The coastline is characterized by an alternation of rocky shores, comprising either gentle continental slopes or masses of granite boulders, and low-lying areas consisting of sandy beaches and mangrove swamps. Sandy beaches represent 34 to $53 \%$ of the total length of the shoreline, as shown in table 1, and they vary in length from 60 to 2,500 meters. The main driving forces of the coastal system are swells that are generated by alternating south-eastern trade winds and north-eastern monsoon waves. This climate regime generates the reversal of the longshore drifting from one season to the next. Rarely, tropical cyclones that form in the southeast of Seychelles generate heavy swells that affect the coasts. The three main populated islands (Mahe, Praslin, la Digue) have 62 beaches, half of which are seriously eroded.

Table 1: Characteristics of coasts and beaches in granitic Seychelles.

\begin{tabular}{|c|c|c|c|c|c|}
\hline \multirow{2}{*}{$\begin{array}{c}\text { Island and } \\
\text { land area } \\
\left(\mathrm{km}^{2}\right)\end{array}$} & \multicolumn{3}{|c|}{$\begin{array}{c}\text { Main characteristics of coasts and } \\
\text { beaches }\end{array}$} & \multicolumn{2}{|c|}{ Importance of beach erosion } \\
\hline & $\begin{array}{c}\text { Coastline } \\
(\mathrm{km})\end{array}$ & $\begin{array}{c}\text { Sandy } \\
\text { coastline } \\
(\mathrm{km} \text { and } \\
\%)\end{array}$ & $\begin{array}{c}\text { Number } \\
\text { of beaches }\end{array}$ & $\begin{array}{c}\text { Number of } \\
\text { beaches which } \\
\text { are seriously } \\
\text { eroded }\end{array}$ & $\begin{array}{c}\text { Number of eroded } \\
\text { beaches with hard } \\
\text { protection } \\
\text { structures }\end{array}$ \\
\hline Mahe (154) & 105 & $36(34 \%)$ & 23 & 12 & 7 \\
\hline Praslin (37) & 43 & $21(48 \%)$ & 24 & 16 & 11 \\
\hline $\begin{array}{l}\text { La Digue } \\
(10)\end{array}$ & 15 & $8(53 \%)$ & 15 & 7 & 5 \\
\hline Total & 163 & $65(40 \%)$ & 62 & 33 & 23 \\
\hline
\end{tabular}

NB The number of eroded beaches is preferred to a figure for the beach length that is affected by erosion because we consider that a beach that is partly eroded is globally threatened, either for natural or human reasons.

\subsubsection{Main causes of beach erosion}

In granitic Seychelles, $60 \%$ of the beach erosion is due to a combination of natural factors and human interferences with physical processes [5].

Firstly, it must be emphasized that the sand budget of beaches has been seriously affected by the diminution of the sediment supply which occurred after the coral reef reached the sea level as it stabilized around 3,000 years BP [5, 6]. More recently, certain changes in monsoon patterns and an increase in storm frequency and intensity have had serious impacts both on sand drifting and on beach budgets. On the north-western coast of Praslin, changes in coastal currents affected the direction and the volume of sediment transport, which resulted in rapid beach erosion that destroyed a coastal road [7]. The analysis of meteorological data indicates a recent increase in the number of storms. The 14 storms that were recorded in the period between 1963 and 1976 represent $50 \%$ of the total number of storms that have affected the granitic Seychelles region (5 to $10^{\circ} \mathrm{S}$ and 55 to $60^{\circ} \mathrm{E}$ ) between 1852 and 1990 . El Niño events of 1982-1983, 1987-1988 and 1997-1998 have had serious effects in Seychelles as they affected the climate regime and generated unusual stormy events. The storm that occurred 
in 1997 had serious impacts on most beaches, as shown in previous works [8]. As tidal data are recent and incomplete, the role of sea level rise in beach evolution is very difficult to estimate [5].

Various human factors have produced or aggravated beach erosion. Until the beginning of the 1990s, sand extraction was freely conducted on beaches and river mouths by residents and building companies. Since then, the reinforcement of sand mining regulations and the production of granitic sand as an alternative material for construction have reduced coastal extraction. However, cleaning has an adverse effect on the sediment budget of beaches as systematic raking removes all coral debris that stabilize beaches and provide them with sand. As a consequence of the narrowness of plains, many residents have reclaimed the inner part of the reef flat in order to extend their properties. Since 1969, coastal reclamation has accelerated as the independence of Seychelles (1976) has stimulated development. On the eastern coast of Mahe, the main fishing harbour of Victoria was extended (1973) and the international airport of Pointe Larue was inaugurated (1971). Since then, the need for flat land for industrial, residential and infrastructural needs has led to the reclamation of some 700 hectares. Coastal reclamation has destabilized sediment cells. The disappearance of mobile sand banks, the disturbance of sand drifting and changes in current patterns have accelerated beach erosion. The induced diminution of sand supply has encouraged residents to build groynes in order to stabilize beaches in front of their properties. As a consequence, destabilization of beaches has extended downdrift. The aggravation of beach erosion has also led to the construction of seawalls. The destruction of coral reefs in reclaimed areas has exacerbated the erosional impacts of storms on back-reef beaches. The narrowness of coastal plains has also encouraged the construction of roads that are very close to the shoreline. Due to their exposure to storm waves, these roads were protected by hard engineering structures such as seawalls and ripraps. Other common causes of beach erosion are channel dredging in reef flats, reclamation of mangroves, destruction of coastal vegetation and construction of harbours and jetties.

\subsection{The situation of Mauritius}

\subsubsection{The state of beaches}

The Republic of Mauritius consists of two main volcanic islands, Mauritius $\left(20^{\circ} \mathrm{S} 58^{\circ} \mathrm{E}, 1865 \mathrm{~km}^{2}\right)$ and Rodrigues $\left(19^{\circ} \mathrm{S} 43^{\circ} \mathrm{E}, 110 \mathrm{~km}^{2}\right)$, and of about thirty volcanic and coral islets located at a short distance from their coasts. As a consequence of subsidence and erosional processes, the relief is dominated by coastal plains and plateaux. The summits reach $828 \mathrm{~m}$ at Piton de la Petite Rivière Noire in Mauritius and $396 \mathrm{~m}$ at Mont Limon in Rodrigues.

As shown in table 2, the coastline of Mauritius is composed of sandy beaches bordered with fringing coral reefs on $70 \%$ of its length, alternating with mangrove swamps, rocky platforms and cliffs. Most beaches are rectilinear, 20 to $60 \mathrm{~m}$ wide and a few hundred to a few thousand kilometres long. About 200 beaches can be distinguished, more than half associated with hotel and tourism residences. Because of late volcanic eruptions that occurred 1.3 to 1.5 million years ago, the coasts of Rodrigues are mainly made of rocky shores. The sixteen 
sandy beaches only represent $9 \%$ of the total length of the shoreline and are located on the eastern and south-eastern coasts. Most are pocket beaches or small crescentic ones. They range from 2 to $25 \mathrm{~m}$ wide, some being very narrow as a consequence of the receding shoreline. In both islands, the coastal system is driven by oblique swells produced either by the south-eastern trade winds or by southern storms coming from the southwest, both of which generate a northward longshore current. As they are situated in the cyclone belt, Mauritius and Rodrigues can be affected by hurricanes from the east from November to April.

Table 2: Characteristics of coasts and beaches in Mauritius and Rodrigues.

\begin{tabular}{|c|c|c|c|c|c|}
\hline \multirow{2}{*}{$\begin{array}{c}\text { Island and } \\
\text { land area } \\
\left(\mathrm{km}^{2}\right)\end{array}$} & \multicolumn{3}{|c|}{ Main characteristics of coasts and beaches } & \multicolumn{2}{|c|}{ Importance of beach erosion } \\
\hline & $\begin{array}{c}\text { Coastline } \\
(\mathrm{km})\end{array}$ & $\begin{array}{c}\text { Sandy } \\
\text { coastline } \\
(\mathrm{km} \text { and \%) }\end{array}$ & $\begin{array}{c}\text { Number of } \\
\text { beaches }\end{array}$ & $\begin{array}{c}\text { Number of } \\
\text { beaches which are } \\
\text { seriously eroded }\end{array}$ & $\begin{array}{l}\text { Number of eroded } \\
\text { beaches with hard } \\
\text { protection structures }\end{array}$ \\
\hline $\begin{array}{l}\text { Mauritius } \\
(1865)\end{array}$ & 322 & $210(70 \%)$ & $200 *$ & $95^{*}$ & $65^{*}$ \\
\hline $\begin{array}{l}\text { Rodrigues } \\
(110)\end{array}$ & 67 & $6(9 \%)$ & 16 & 8 & 3 \\
\hline Total & 389 & $216(55 \%)$ & $216^{*}$ & $103 *$ & $68^{*}$ \\
\hline
\end{tabular}

NB Asterisked figures are approximate estimations reflecting the complexity of the situation in Mauritius due to the high number of beach sections, which is a consequence of the high level of fragmentation of sediment cells.

\subsubsection{Main causes of beach erosion}

In Mauritius and Rodrigues, the rapid retreat of isolated beaches indicates a marked decrease in sand supply at the scale of geological ages. In some areas, beachrock slabs have replaced sandy beaches and dunes are now bordered with rocky platforms. Storm waves remove beach material that is entirely lost to sediment cells when it is evacuated by rip currents through reef pass. Beach resilience is generally limited in low energy environments where regular waves are not strong enough to take back to the coast the sand that storm waves have deposited on the top of reef flats [9].

In Rodrigues, human-induced beach erosion is very limited due to the low level of development of the coastal zone. Villages are located inland and only three hotels were built on the seashore. The most impacted sector is that of Port Mathurin, the main town, on the northern coast, where land reclamation and coastal dredging were carried out to extend the harbour and to create flat land for future development.

In Mauritius, in most cases, beach erosion is due to a combination of natural and anthropogenic factors. Human-induced disturbances have accelerated sand loss and coastline recession. The degradation of coastal dunes by sand extraction, flattening for construction requirements, or building on the fore dune, has played a major role in beach destabilization on the western, south-western and eastern coasts. The illegal building of around 200 jetties and groynes has disrupted sand drifting and exacerbated erosion on downdrift beaches, in particular on the western (Flic en Flac), south-western (Morne Brabant), northern (Grand Baie) and south-eastern (Mahebourg) coasts. Many changes have occurred since tourism developed in the 1970s. The building of more than 100 hotels and of 
numerous coastal tourism residences and villas has had many impacts as most of the regulations concerning sand mining, building and coastal works, which although agreed over the past two decades, have still not been implemented. Owners of coastal plots and tenants of leases often let land either to private individuals or to tourism companies for speculation. There is much confusion on the status of coastal residents and tourism operators, which makes it difficult to ensure the respect of the law. Furthermore, the rapid development of high standard tourism has encouraged the development of many types of coastal works that lack consideration for their local impacts on sensitive ecosystems or for the potential disturbances caused on adjacent sectors. Boat channels have been dredged in reef flats and passes were widened in reef fronts. In touristic areas, coral sands were mined from public beaches, dunes and reef flats without any official authorization in various circumstances, such as the building of a hotel, for beach reprofiling works or post-storm beach nourishment. Therefore, it can be stated that the main cause of beach erosion is the destabilization of sediment cells, which is caused by the multiplication of uncontrolled coastal works.

\section{The predominance of hard engineering structures in beach erosion management practices}

In Seychelles and Mauritius, beach erosion control is characterized by a resistance strategy that aims at protecting exposed constructions and at fixing the coastline. Over the decades, various types of hard structures have been built, among which seawalls, groynes, ripraps and gabion walls are the most common.

\subsection{Beach erosion control in granitic Seychelles}

By the beginning of the $19^{\text {th }}$ century, seawalls had already been built along the north-eastern coast of Mahe to protect the main town of Victoria, its headquarters and the harbour area. Over the years, coastal residents developed simple techniques for protecting their houses and properties. The first method, still in usage today, consisted of building vertical seawalls. The second technique was the reclamation of a strip of reef flat in front of one's property. This defensive strategy was highly beneficial as the creation of a buffer zone provided efficient protection for the land, while also extending the property on the seaward side. This traditional practice has declined since the passing of the reclamation law in 1961. Over the past two decades, coastal residents facing severe coastal erosion have tried out a third technique. This involves the building and installation of parallel rows of gabions that limit land loss by fixing the coastline. The other two advantages of this solution are its low impacts on both the quality of the landscape, due to the fact that they are buried under the beach, and also on sediment cells dynamics.

The protection of transport facilities such as roads, harbours and airports, which comes within the jurisdiction of the Division of Environment, has been achieved by the construction of concrete seawalls and cemented groynes until the 
1980s. In most sites, groynes failed to induce sand accretion because of the high level of fragmentation of sediment cells or because they were installed in the quiet waters of sheltered bays. Some of the seawalls collapsed under the pressure of storm waves, which led to significant damage to coastal roads. Until the 1990s, seawalls were repaired. Then, the opening of quarries in the granites of Mahe and Praslin sustained the development of a new technical solution. The extraction of massive blocks of granite permitted the construction of solid ripraps that were installed along coastal roads, in front of threatened facilities and around reclaimed plots. With the exception of la Digue Island, where there is no quarry for granite extraction, ripraps have replaced seawalls. The efficiency of these boulder ramparts has encouraged the Division of Environment to systematically use such protections. On the western coast of Praslin, which is affected by rapid beach erosion, it was decided to extend ripraps to non-eroded beaches as a preventative measure. As a result, the amount of artificial shoreline reaches 30 to $40 \%$ depending on the island. As most artificial shores were initially sandy coasts, hard defences have reduced the attractiveness of islands. Broken seawalls and groynes and useless structures which were built hastily after storm events are still lying on beaches, spoiling the scenery and disturbing human activities.

The setback distance for construction on the shore is only 15 metres, so most hotels, guesthouses and restaurants were built very close to the sea. Their exposure to storm waves has led to the systematic use of seawalls that have accelerated beach erosion and caused the disappearance of some beaches. As a result, many hotels now only have very degraded beaches to offer their guests.

Due to the weakness of the law and the lack of control measures, both hotel operators and coastal residents have made endless mistakes and damaged the environment by trying out numerous hard protection measures. The lack of a consistent management of sediment cells has led to the gradual destabilization of rectilinear beaches that are hydrodynamically driven by the longshore current. In contrast, the best preserved beaches are isolated pocket or cove beaches.

\subsection{Beach erosion control in Mauritius and Rodrigues}

In Mauritius, beach erosion control is under the jurisdiction of the Ministry of Environment and Quality of Life (MEQL), which is represented by the Division of Environment (DoE) in Rodrigues.

The intense storms of the 1990s, and in particular tropical cyclone Hollanda which occurred in 1994, caused severe damages to cemeteries (Saint Félix, Cap Malheureux), coastal roads (Grand Baie, Saint Félix) and public beaches (Pomponnette, Flic en Flac, Grand Baie, Morne Brabant) in all areas. In order to limit the destructive effects of such events in future, the Government of Mauritius carried out protection works on the most affected sites and adopted in 1999 what can be considered as the first beach erosion control plan. Massive gabion walls up to 7 meters high in the north were installed at the foot of coastal dunes. Traditional protection structures such as cemented seawalls were abandoned and systematically replaced by gabions. Like in Seychelles, the opening of quarries - here, in volcanic rocks - offered new possibilities for 
coastal protection. In some places (Grand Baie, Saint Félix), groynes had also been trialled, which failed to trap sand. Thus, in the 1990s, gabions spread to all coastal regions. They were installed in seaside resorts, urban areas and natural sites without any consideration either for the importance and value of the constructions that they defended, or for their environmental impacts. Continuous gabion walls were erected along public beaches even where buildings or roads were not exposed. The policy which became apparent during this decade consists in a strategy of systematic resistance to wave attack by fixing the coastline. An official list of the sites to be defended with gabions was drawn up, detailing 15 kilometres of beach that required urgent treatment; of which, 5 kilometres had been completed by 2000 . Within a few years the government plan resulted in the construction of gabions along $50 \%$ of the total length of public beaches. On the western coast (Flic en Flac), as gabions were destroyed by waves, the chicken wire and volcanic rocks they contained spread onto the beach and caused injuries to visitors. In other cases (Pomponnette), massive gabion walls proved to be useless because of the resilience of the beach. Such errors were due to lack of national expertise. The University of Mauritius (UoM) and the Mauritius Oceanography Institute (MOI) do not have skills in the field of coastal dynamics. In this context, some erroneous views prevail, such as the belief that maintaining the gabions is favourable to sand deposition and therefore to beach progradation.

Where hotels were built too close to the sea, hard structures were constructed to protect them. This situation refers mainly to the small to medium size hotels of the 1970s and 1980s that offer rooms overlooking the sea (Grand Baie, Belle Mare, Flic en Flac). Wave reflection on the walls accelerated beach erosion and caused damage to hotels.

In Rodrigues, massive ripraps were built at Port Mathurin to protect the reclaimed area from wave attack. As few houses and hotels were built on dunes, hard structures are scarce. Seaside hotels are protected by seawalls and groynes. The expected development of tourism over the coming decades might change this situation as the Division of Environment often takes an interventionist approach. After erosion events in the late 1990s, truck tyres were installed on the southern coast of Ile aux Sables, a nature reserve.

\subsection{Beach erosion management in Small Island Developing States (SIDS)}

The situations of Seychelles and Mauritius share many common features with other SIDS. Firstly, the ineffectiveness of environmental policies and coastal planning is partly due to a complex heritage that encompasses a mixture of French and English laws inherited from the successive colonial periods. Since independence (1968 in Mauritius, 1976 in Seychelles), new regulations have been adopted ad hoc which do not form a consistent framework.

The background of economic development (from the 1970s) in relation to the adoption of coastal policies, laws and planning (in the 1990s), explains the low level of implementation of regulations and the increase in the number of uncoordinated technical interventions that aimed at controlling beach erosion.

Additionally, both countries lack human, financial and technical capacities for improving coastal management. Coastal managers lack proper diagnostic data to 
make the right choices for mitigating beach erosion. The same techniques are employed whatever the situation may be. Presently, ripraps are systematically installed on the eroding coasts of Seychelles and gabions on those of Mauritius. Due to their remoteness from developed countries, these countries do not benefit from the advancements made in western states over the past decades.

Moreover, hard structures are considered as progress in coastal management because they provide security to people and protection of possessions. A public survey carried out by the author in 2005 indicated that visitors were satisfied with the installation of gabions for safety reasons. Landscapes have no specific value in Seychellois and Mauritian contexts.

\section{New trends in beach erosion management}

\subsection{General factors that have led to progress}

Over the past ten years, national policies for beach erosion control have evolved under the influence of various internal and external factors. One of the main reasons for progress was the establishment of the Regional Environment Programme of the Indian Ocean Commission (PRE-COI 1995-2003) supported by the European Union. This programme gave priority to coastal issues and in particular to the mitigation of beach erosion and coral reef degradation. Thereby, scientific studies were encouraged and supported, and national capacities and policies were assessed. The results of expert reports were presented at the congress of Mahe (2000), where a regional plan of action was developed. In 2002-2003, a practical guide dealing with beach erosion management was edited [10] and a training programme was organized to support capacity building. It took place at the University of Mauritius where it gathered coastal managers from diverse administrations, members of NGOs and tourism operators. Field excursions encouraged case study analysis and experience sharing. This training had practical consequences: the development of bilateral collaboration between the French territory of Reunion, which possesses expertise in the field of coastal geomorphology and beach management, and the neighbouring SIDS; the creation of beach monitoring programmes, in particular in Seychelles (2003), Rodrigues (2003) and Mauritius (2005); and the carrying out of complementary studies aiming at supporting coastal development and management, such as the beach vulnerability assessment of Rodrigues in 2003 [11].

The PRE-COI supported the development of political consciousness and thus encouraged the progress of national policies. In Seychelles, the setback distance was increased from 15 to 25 meters wherever this measure can be applied without obstructing development projects. In Mauritius, in 2003, a new procedure for beach erosion management was discussed with representatives of the MEQL and set up with the purpose of putting an end to hurried technical interventions [12].

Progress was also supported by the building of a new generation of high standard hotels 80 to 100 meters from the high water mark, with tropical gardens separating the private space of rooms from coastal leisure facilities. In a country 
where the setback distance is only 15 meters, this new hotel concept plays a major role in the reduction of the adverse effects of buildings on beach dynamics and evolution. It is presently being developed in Seychelles by tourism companies from Mauritius.

\subsection{The role of the private sector in the diversification of erosion control techniques}

In Mauritius, much progress in beach erosion management is due to hotel managers that have experimented with new techniques for controlling beach erosion without reducing the high economic value of beaches. Thus, hotel beaches have acted as field laboratories for testing alternative soft engineering strategies. The pragmatism of tourism operators who look for solutions that are adapted to local situations is favourable to innovation and therefore to the diversification of interventions. New kinds of hard structures were tested, such as underwater (Legends hotel) and submerged breakwaters (Saint-Géran and Sands hotels), buried gabions (Saint-Géran hotel) and sand bags (Palmar hotel). Soft techniques were introduced, which have now become standard, such as mechanical and manual beach reprofiling and the stabilisation of sand dunes with indigenous plants and beach restoration. Artificial beach nourishment became more common after erosion peaks due to storm waves dispersed beach sand on reef flats. The technique consists of pumping sediments that were taken away by the waves onto reef flats. Generally, this operation is completed by the provision of extra sand collected either in coastal dunes or on reef flats. In 2002, after tropical cyclone Dina, about $25 \%$ of hotel managers admitted that they have had recourse to beach nourishment to accelerate beach recovery. This figure is definitely less than the true amount. Extraction zones are unknown because sand mining is prohibited, so an effort should be made to regulate this practice in order to limit its potential adverse impacts on coastal dynamics. Its regulation would make it possible to encourage sustainable beach nourishment with sand taken only from authorized sites, thus promoting environment-friendly solutions $[12,13]$. Prospecting campaigns should be carried out on the extended submarine platforms that surround Mauritius, Rodrigues and Seychelles for evaluating underwater sand stocks [12].

In Seychelles, adaptive measures were initiated by resort island managers. In Bird $\left(1 \mathrm{~km}^{2}\right)$ and Desroches $\left(4 \mathrm{~km}^{2}\right)$ coral islands, the recession of the coastline destroyed hotel bungalows in 1988 and 1991 respectively. In both cases, all buildings were relocated 100 meters inland. The creation of a natural buffer zone was critical as no damage has occurred since then.

\subsection{The role of politics in coastal management progress}

In Mauritius, the context of the free market and high tourism performance has been favourable to the improvement of beach erosion control practices as the pragmatism and initiative of hotel managers has led to experimentation in new protection and prevention techniques. Another advantage of the tourism system is that most investors are locals who have a long-term view of tourism 
investment. This situation is favourable to the pursuit of sustainable solutions to problems. Furthermore, local investors have an empirical knowledge of coastal dynamics and therefore a good idea of what or what not to do in coastal development. As $70 \%$ of tourism operators belong to the association of hotels and restaurants of Mauritius (ARHIM), they are also aware of the many experiments made at the national scale, and of their findings. This context is favourable to performance and progress.

The situation in the Seychelles is different. Politically, after independence (1976) and a coup d'état (1977), Seychelles became a socialist country opposed to liberalism, which discouraged local initiatives and limited capital formation. At the beginning of the $1980 \mathrm{~s}$, internal political problems discouraged foreign investment. As a result, the tourism sector stagnated and financial and monetary problems appeared. Despite the settlement of political issues and the adoption of multipartism (1991), tourism investments are still limited and arise mainly from foreign companies [14]. This global context is not favourable for progress.

\section{Conclusion}

In Small Island Developing States such as Seychelles and Mauritius, beach erosion raises important economic and environmental issues. Both natural and anthropogenic factors have accelerated coastline recession over the past decades and scientific predictions are globally pessimistic regarding the impacts of climate change on the evolution of coral reefs and back-reef beaches.

In such context, there is an urgent need for coastal managers to work with tourism operators to develop capacity building and to promote consistent policies in the field of beach erosion control. As shown in this paper, regional environment programmes supported by international organizations and NGOs can play a major role in the creation of well-founded regional and national strategies for beach erosion management and their implementation. Currently, the main priorities are to support scientific studies and international expertise in order to put a stop to the systematic installation of hard engineering structures on eroding beaches, and to support the development of techniques that work with coastal processes. This is necessary primarily to improve the efficiency of technical interventions, both in financial and technical terms, and also for integrating environmental and socioeconomic issues in beach erosion control. An integrated beach management strategy is needed to address all threats to coastal environment degradation because it can seriously affect the attractiveness of beaches and therefore the success of insular tourism destinations. As an example, some resort islands of the Maldives and sandy beaches of the island of SaintMartin (lesser Antilles) have lost their tourism function because of inadequate coastal management.

\section{Acknowledgements}

I am grateful to the Indian Ocean Commission, MEQL (Mauritius) and Divisions of Environment in Seychelles and Rodrigues for financial and technical support. 


\section{References}

[1] Bird, E.C.F., Coastline changes, Wiley \& Sons: Chichester, New York, Brisbane, Toronto, Singapore, 1985.

[2] Bird, E.C.F. \& Schwartz M.L, The world's coastline, Van Nostrand Reinhold Company: New York, 1985.

[3] Philips, M.R. \& Jones A.L., Erosion and tourism infrastructure in the coastal zone: Problems, consequences and management. Tourism Management, 27, pp. 517-524, 2006.

[4] Wong, P.P., Where have all the beaches gone? Singapore Journal of Tropical Geography, 24(1), 2003.

[5] Cazes-Duvat, V., Les littoraux des Iles Seychelles, L'Harmattan: Paris, 1999.

[6] Camoin, G.F., Montaggioni, L.F., Braithwaite, C.J.R., Late glacial to postglacial sea levels in western Indian Ocean. Marine Geology, 206, pp. 119146, 2004.

[7] Shah, N.J., Coastal zone management in Seychelles. Proc. of the National Workshop on Integrated coastal zone management in Seychelles, eds. C.G. Lundin \& O. Linden, pp. 14-125, 1995.

[8] Cazes-Duvat, V., Atlas de l'environnement côtier des îles granitiques de l'archipel des Seychelles, Louis Jean: Gap, 2001.

[9] Cazes-Duvat, V., Les impacts du cyclone Kalunde sur les plages de l'Île Rodrigues (océan Indien occidental). Zeitschrift Für Geomorphologie, 49 (3), pp. 293-308, 2005.

[10] Cazes-Duvat, V. (coord.), Delmas-Ferré, M., Troadec, R., Manuel de suivi et de traitement de l'érosion côtière. Pays de la Commission de l'océan Indien. PRE-COI/ $/ 7^{\mathrm{e}}$ FED-UE, Le Printemps: Quatre Bornes, 2002.

[11] Duvat, V., Les littoraux coralliens des petites îles de l'océan Indien (Mascareignes, Seychelles, Maldives). Volume 2 - Aménagement et gestion, Institut Océanographique: Paris, 2007.

[12] Cazes-Duvat, V., Paskoff, R., Les littoraux des Mascareignes entre nature et aménagement, L'Harmattan: Paris, 2004.

[13] Bird, E.C.F., Beach management, Wiley \& Sons: Chichester, New York, Brisbane, Toronto, Singapore, 1996.

[14] Gay, J.-Ch., Tourisme, politique et environnement aux Seychelles ». Revue Tiers-Monde, t. XLV, 178, pp. 319-339, 2004. 